\title{
Mexican physical education teacher's self-reported and self-perception of teaching style
}

\author{
Auto-percepción y auto-reporte de estilos de enseñanza en profesores de educación física \\ mexicanos
}

\section{Autorrelato e autopercepção do estilo de ensino do professor mexicano de educação física}

Oscar Núñez Enríquez ${ }^{a}$ (D) , Julio César Guedea-Delgado ${ }^{a}$ (D),

Gabriel Gastelum-Cuadras ${ }^{\mathrm{a}}$ (D), Ena Monserrat Romero-Pérez ${ }^{\mathrm{b}}$ (D),

Ramón Candia Lujána (D), Raúl Josué Nájera-Longoria** (iD

Keywords:

Physical Education;

Teaching style;

Perception;

Social Pedagogy.
Palabras-clave:

Educación Física;

Estilo de enseñanza;

Percepción

Pedagogía Social.

Palavras-chave:

Educação Física;

Estilo de ensino;

Percepção;

Pedagogia Social.

\begin{abstract}
To understand the self-reported and perception of teaching style used among Mexican physical education teachers. Participants included 104 ( $n=41$ females and 63 males) elementary physical education teachers from northern Mexico. Results showed that a traditional teaching style tends to be mainly used either by male and female's physical education teachers. Showing differences between genders and teaching styles. Female teachers tend to combine a traditional teaching style with one that connects with students engaging in physical activity, developing positive values and attitudes. Cultural context plays an important aspect when developing a teaching self-perception.
\end{abstract}

\section{RESUMEN}

Conocer el auto reporte y percepción del estilo de enseñanza entre docentes de educación física mexicanos. Participantes incluyeron 104 ( $n=41$ mujeres y 63 hombres) maestros de educación física básica del norte de México. Los resultados mostraron que un estilo de enseñanza tradicional tiende a ser utilizado principalmente por profesores de educación física, tanto hombres como mujeres. Mostrando diferencias entre géneros y estilos de enseñanza. Las maestras tienden a combinar un estilo de enseñanza tradicional que conecta con los estudiantes a participar en actividad física, desarrollando valores y actitudes positivas. El contexto cultural juega un aspecto importante a la hora de desarrollar una autopercepción docente.

\section{RESUMO}

Compreender o autorrelato e a percepção do estilo de ensino utilizado por professores de educação física mexicanos. Os participantes incluíram 104 ( $n=41$ mulheres e 63 homens) professores de educação física elementar do norte do México. Os resultados mostraram que um estilo de ensino tradicional tende a ser usado principalmente por professores de educação física do sexo masculino e feminino. Mostrando diferenças entre gêneros e estilos de ensino. As professoras tendem a combinar um estilo de ensino tradicional com um que conecta os alunos em atividades físicas, desenvolvendo valores e atitudes positivas. O contexto cultural desempenha um aspecto importante no desenvolvimento da autopercepção do ensino.

\footnotetext{
aUniversidad Autónoma de Chihuahua, Facultad de Ciencias de la Cultura Física. Chihuahua, Chihuahua, Mexico

bUniversidad de Sonora, Dirección de Ciencias Biológicas y de Salud, Departamento de Ciencias del Deporte y Actividad Física. Hermosillo, Sonora, Mexico.
}

\footnotetext{
*Corresponding Author:

Raúl Josué Nájera-Longoria

E-mail: jnajera@uach.mx
} 


\section{INTRODUCTION}

Over the past decades physical education (PE) has navigated through different ways in order to respond to a present time need or discourse (Kirk, 2009). This can be explained because PE is the first opportunity to implement a [pedagogical] practice that adds elements to this discourse. For instance, in Mexico, there has been six different pedagogical approaches implemented, responding to specific socio-cultural and political needs (Mexico, 2006, 2017). The first pedagogical approach appeared in early 1940's with a military-based focus. In early 1960's was implemented a sports-based approach. In mid 1970's a psychomotor approach. In late 1980's was utilized a health-related approach. In mid 1990's appeared what could be considered the approach that gave teachers the opportunity to combine different aspects into their pedagogical practice; the dynamic and motor integration approach. This one, allowed teachers to use for the first-time different teaching styles within their teaching practice. Lastly, in 2006 was implemented the competency-based approach. These approaches contributed in different ways how teachers built the selfperception they have hold over the years within Mexican PE contexts.

According to Mirandé (2008) social roles can affect how individuals perceive themselves within the cultural expectations around a society. For instance, in Mexico social expectations are based on a gender-hierarchy that affects all levels of society including the educational system and teaching practice. For instance, teaching roles are based on the premise that leadership positions such as administration and PE teachers should be males and classroom teachers should be females. This is consistent with Sykes (2004) mentioning that teaching, pedagogy and practice is affected by a status quo that positions female participation under male involvement. Fortunately, this scenario is changing and ShapiraLishchinsky (2007) study found that female teachers tend to be more committed in their teaching practice and, are promoters of a social justice climate within their workplace compared to men. Similarly, Bastick (2000) reported that female teachers showed higher values of motivation scale than males, thinking in the impact of their teaching practice. Although, Bastick research also indicated that years of experience helped this motivation increase. Brennan and Robison (1996), found that male teachers showed an increased interest to question their teaching ability that can affect students' behavior than in previous years. As in Bastick study, it seems that years of experience is a factor that allow teachers to move beyond their teaching practice, and helped them to re-shape their self-perception.

According to Kulinna and Cothran (2003) PE teacher's self-perception is shaped on numerous experiences lived over the years, and each one of these experiences has helped them to form what they identify as their 'inception' of education. The inception of education is based on the premise that focuses in finding what would be the best way to teach and the best way to facilitate students' learning. However, this premise and its' ways to be implemented can be affected by external factors such as cultural context. For instance, Brennan and Robison (1996) research showed that teacher's ability is affected and limited by external factors such as the family background and specific students' characteristics. Although Brenan and colleagues also mentioned that within their study these factors challenged teachers' abilities, although neither male nor female teachers' self-perception was greatly changed. However, it can be said that in somehow teachers' self-perception changed in order to fit their teaching ability. Similarly, Liu (2008) study among teacher candidates and first year teacher's self-perception, showed that their teaching efficacy beliefs are affected by the background, although, female participants showed more concern on how this affects their abilities than male participants. As such, it seems that external factors are elements that affect how teachers build their own self-perception and abilities shaping their teaching identity.

There are several factors that can be added into teachers' pedagogical practice (O'Sullivan, 2011), but it is important to consider that these aspects can have an impact into their own self-perception affecting their own epistemology. For instance, Harvey et al. (2020) mentions that PE teachers are highly influenced by students' energetic and enthusiastic responses while participating in class. These responses have helped teachers change their teaching self-perception, seeing beyond their pedagogical practice and wanting to add elements that can increase motivation and enthusiastic engagement. Thus, it is important to consider students' engagement as a way to help teachers' perspective to change (Jesus et al., 2020). However, Harvey and colleagues also mentioned that cultural background influences how teacher's report their self-perception and the ways they interact with their students. Although, by having a support system, teachers are willing to move beyond their scope. This is consistent with Darling-Hammond and McLaughlin (2011) mentioning that 'Teachers learn by doing, reading, and reflecting; by collaborating with other teachers; by looking closely to students and their work; and by sharing what they see' (p. 83). As such, it is important to be willing to understand how different elements can affect a pedagogical practice.

According to Delgado (2015) teaching styles are important elements to be considered as part of a pedagogical practice. The spectrum of teaching styles utilized around the world varies with regards of the context and the country having similarities and differences (Mosston and Ashworth, 2002). For instance, Mosston and Ashworth (2002) categorized ten different teaching styles; command, practice, reciprocal, selfcheck, inclusion, guided discovery, problem solving, individual, learner initiated, and self-teaching, which ultimate goal is to provide a systematic process to deliver the content planned. Similarly, Contreras et al. (2001) categorized seven teaching styles; direct, task development, peer-teaching, small-sided, individual, 
problem solving, creativity and guided-discovery. Both authors portrayed in opposite ends of their teaching styles spectrums, in one end, a more 'teacher-centered' style, named command style and direct teaching style respectively. On the other end, a more 'student-centered', named self-teaching style and guided discovery, although, in between these ends, there are other styles offering its own decision-making structure. These spectrums, seek to influence the motivational climate within the PE class, utilizing a way fitting the context, cultural background and years of experience PE teachers hold.

A characteristic of teaching styles is that provides a spectrum of responses and can be considered as a bridge between the different elements utilized in a pedagogical practice (Kulinna and Cothran, 2003). Another characteristic of a teaching style is that serves as a pedagogical tool that can be combined with a pedagogical approach or model in order to connect or match students' interest, motivation and learning (Guedea-Delgado, 2010). However, it is important to say that these characteristics presents a risk, since in different ways teachers tend to use a teaching style that matches their interest, identity, self-perception and personality as a way to deliver the content planned for the class (Cothran et al., 2005; Kulinna and Cothran, 2003). For instance, Luguetti et al. (2018) mentions that a common aspect among teachers is the opportunity to feel comfortable when delivering the content planned for the class, a reason is because this responds to the epistemology of their teaching identity. Although, Luguetti and colleagues also mention that challenging teachers' identities places them in an uncomfortable position, but at the same time, provides an opportunity to find ways that meet students' interest, motivation and learning to engage in physical activity. As such, understanding the importance of using a specific teaching style as pedagogical tool is a relevant aspect to consider in order to bridge these pedagogical aspects shaping teachers' self-perception and abilities.

It is important to understand the influence of these factors and how these play a relevant position developing teachers' pedagogical identities, roles and whether different aspects can be woven together as part of their pedagogical self-perception (Nunez Enriquez and Oliver, 2020). This is consistent with Morgan et al. (2005) mentioning that implementing a teaching style it creates an effect within teachers, since, is a way to build-up an appropriate environment and class behavior. However, these aspects are influenced by teachers' attitudes, years of experience and context, thus, practicing a teaching behavior that can either affect the practice and pedagogy implemented. According to Curtner-Smith et al. (2001) there is a strong line of research that focuses in the impact teaching style has over the class environment, teachers' attitudes and its impact in delivering the content planned for PE and physical activity settings. However, there is a lack of studies that explore the self-reported perception use of teaching styles among Mexican PE teachers. In this way the purpose of this research was to comprehend the use of teaching styles and self-reported and selfperception among Mexican PE teachers.

\section{MATERIALS AND METHODS}

\section{RESEARCH DESIGN}

This study was a comparative research study (Cox et al., 2009), utilizing a transversal analysis approach (Vignollet et al., 2008), since this type of analysis brings relevant data acquisition in educational fields. To establish a comparison based on PE teachers' gender and the use of the different teaching styles. It was also used a correlational analysis in order to establish the relationship between the self-perception and self-reported teaching style among elementary physical education teachers in the city of Chihuahua, Mexico.

\section{PARTICIPANTS}

Participants of this research project were 104 elementary PE teachers from the City of Chihuahua, Mexico ( $n=41$ females and 63 males). This represents the $70 \%$ of total PE teachers in the City of Chihuahua schools' districts. Chihuahua is located at the Northwest region of Mexico. The average age was of 42.2 years old \pm 9.5 , and splitting the sample by gender, the mean age for woman $42.2 \pm 9.9$ and males $42.3 \pm 9.3$ years. Their mean in teaching years of experience was $15.7 \pm 9.9$ years, women had an average of $16.3 \pm 7.5$ and males $15 \pm 8.6$. Inclusion criteria included being K-6 level PE teachers from the City of Chihuahua. Permits and authorizations were requested through the Chihuahua Board of Education. All subjects participated voluntary and considering ethical Helsinki procedures to deal with persons.

\section{INSTRUMENT}

Participants in this study completed the questionnaire Estilos de enseñanza en educación física [Teaching Styles in Physical Education] (MerinoBarrero et al., 2017) that offers a panoramic view about the association and preferred self-perception TS used in PE. The questionnaire includes 20 items divided in 5 categories or dimensions: traditional, individualized, participative and social, cognitive and creative. Subjects were asked to respond to each item in a 5-point likert scale ( 1 = Totally agree and $5=$ Totally disagree). The authors report a Cronbach's alpha of 0.82 and highly recommend its use to address theoretical tendency in PE teachers. The alpha de Cronbach its important because provides measure of the internal consistency and reliability of the scale, and it is expressed as a number between 0 and 1 (Tavakol and Dennick, 2011; Virla, 2010).

\section{PROCEDURE}

This research project was approved by the Research Committee Board of the Faculty of Physical Culture Sciences at the Autonomous University of Chihuahua approval code 28112017-107. It included presenting the project to the Chihuahua Board of Education, the Physical Education department heads, and the Physical Education 
curriculum supervisors from the different school districts in the City of Chihuahua, Mexico. It was also presented to all PE teachers ( $N=182)$ during every school district scheduled meeting at different dates and districts over a period of three months. From the total of PE teachers the City of Chihuahua holds, only 129 teachers accepted an open invitation to be part of the project but only 104 completed the instrument.

After the completion of each PE programmed meeting, the curriculum supervisors provided a slot to explain the project and answer the questionnaire. First, the research project was presented and explained to all PE teachers that attended these meetings. Once the project was explained, voluntary consent sheets were provided to those interested to participate in the project. Participants were asked to sign a voluntary consent sheet. Then, a thorough explanation of the questionnaire was provided and individual explication was carried out if asked for. Finally, participants were giving a paper copy of the questionnaire to be answer, once it was completed a quick review was given guaranteeing no item was left in blank.

\section{DATA ANALYSIS}

The descriptive statistics were expressed as a mean and standard deviation for each variable. After the normalization of the data was carried out, one-way ANOVA was used to analyze differences by gender and Cohen d effect size allowed us to determinate how strong the differences are. Repeated measures analysis with Bonferroni correction was used to analyze differences between categories by gender, and finally bivariate coefficient Pearson Product Moment Correlation Coefficient was carried out to review the relationship between variables. Significance was set at an alpha level of 0.05 in SPSS version 18.

\section{RESULTS}

Table 1 shows the mean and standard deviations values for every teaching style category. In addition, no differences reported by gender comparison. However higher values were found in traditional and cognitive categories compared to the resting teaching styles. Cohen effect size in all the comparisons is less than 0.2, representing trivial responses.

There was a significant main effect for comparisons for categories $p<0.05$ and revealed higher tendency to the uses of this PE style compared to the rest categories. These finding were demonstrated in the cognitive category as well, which means this could be the second most used style, no matter the fact of the gender (see Figure 1).

On the other hand, weak $(0.0-0.3)$ to moderate (0.3-0.7) bivariated correlation in either traditional, individualizer, participative \& social, cognitive and creative was showed after Pearson correlation test. However, all of the variables have statistically significance in the male sample (See Table 2).

Within the female sample weak (0.0-0.3) to moderate (0.3-0.7) and even strong (0.7-1.0) bivariated correlation in either traditional, individualizer, participative \& social, cognitive and creative values. Despite this, some correlations were not statistically significative (See Table 3).

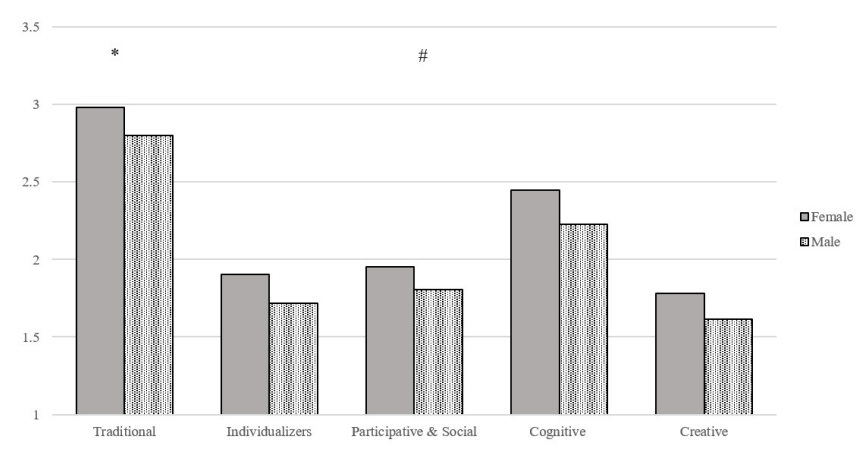

Figure 1. Comparison between categories by gender. *Statistical differences compared to the other categories. \#Statistical differences compared to the rest categories.

Table 1. Teaching styles comparison by gender.

\begin{tabular}{|c|c|c|c|c|c|}
\hline Categories & Gender & Mean \pm SD & $\boldsymbol{F}$ & $p$ & $\begin{array}{c}\text { Cohen d effect } \\
\text { size }\end{array}$ \\
\hline \multirow{2}{*}{ Traditional } & Male $(n=63)$ & $2.7 \pm 1.1$ & \multirow{2}{*}{$F(1,102)=0.86$} & \multirow{2}{*}{0.36} & \multirow{2}{*}{0.2} \\
\hline & Female $(n=41)$ & $2.9 \pm 0.7$ & & & \\
\hline \multirow{2}{*}{ Individualizers } & Male $(n=63)$ & $1.7 \pm 0.9$ & \multirow{2}{*}{$F(1,102)=0.76$} & \multirow{2}{*}{0.39} & \multirow{2}{*}{0.2} \\
\hline & Female $(n=41)$ & $1.9 \pm 1.1$ & & & \\
\hline \multirow{2}{*}{ Participatives \& Social } & Male $(n=63)$ & $1.8 \pm 0.9$ & \multirow{2}{*}{$F(1,102)=0.52$} & \multirow{2}{*}{0.47} & \multirow{2}{*}{0.1} \\
\hline & Female $(n=41)$ & $1.9 \pm 1.1$ & & & \\
\hline \multirow{2}{*}{ Cognitives } & Male $(n=63)$ & $2.2 \pm 0.9$ & \multirow{2}{*}{$F(1,102)=1.6$} & \multirow{2}{*}{0.21} & \multirow{2}{*}{0.2} \\
\hline & Female $(n=41)$ & $2.4 \pm 0.8$ & & & \\
\hline \multirow{2}{*}{ Creatives } & Male $(n=63)$ & $1.6 \pm 1.0$ & \multirow{2}{*}{$F(1,102)=0.65$} & \multirow{2}{*}{0.42} & \multirow{2}{*}{0.1} \\
\hline & Female $(n=41)$ & $1.7 \pm 1.0$ & & & \\
\hline
\end{tabular}

Source: Own elaboration. 
Table 2. Coefficient correlation in the male sample $(n=63)$.

\begin{tabular}{|c|c|c|c|c|c|c|}
\hline & & Traditional & Individualizers & $\begin{array}{c}\text { Participative \& } \\
\text { social }\end{array}$ & Cognitive & Creative \\
\hline \multirow{2}{*}{ Traditional } & Correlation & - & .313 & .276 & .363 & .253 \\
\hline & $p$ & & .012 & .028 & .003 & .045 \\
\hline \multirow{2}{*}{ Individualizers } & Correlation & .313 & - & .739 & .634 & .654 \\
\hline & $p$ & .012 & & .000 & .000 & .000 \\
\hline \multirow{2}{*}{ Participative \& social } & Correlation & .276 & .739 & - & .678 & .681 \\
\hline & $p$ & .028 & .000 & & .000 & .000 \\
\hline \multirow{2}{*}{ Cognitive } & Correlation & .363 & .634 & .678 & - & .644 \\
\hline & $p$ & .003 & .000 & .000 & & .000 \\
\hline \multirow{2}{*}{ Creative } & Correlation & .253 & .654 & .681 & .644 & - \\
\hline & $p$ & .045 & .000 & .000 & .000 & \\
\hline
\end{tabular}

Source: Own elaboration.

Table 3. Coefficient correlation in the female sample $(n=41)$.

\begin{tabular}{|c|c|c|c|c|c|c|}
\hline & & Traditional & Individualizers & $\begin{array}{c}\text { Participative \& } \\
\text { social }\end{array}$ & Cognitive & Creative \\
\hline \multirow{2}{*}{ Traditional } & Correlation & - & .084 & .293 & .500 & .295 \\
\hline & $p$ & & .600 & .063 & .001 & .061 \\
\hline \multirow{2}{*}{ Individualizers } & Correlation & .084 & - & .643 & .428 & .538 \\
\hline & $p$ & .600 & & .000 & .005 & .000 \\
\hline \multirow{2}{*}{ Participative \& social } & Correlation & .293 & .643 & - & .609 & .699 \\
\hline & $p$ & .063 & .000 & & .000 & .000 \\
\hline \multirow{2}{*}{ Cognitive } & Correlation & .500 & .428 & .609 & - & .634 \\
\hline & $p$ & .001 & .005 & .000 & & .000 \\
\hline \multirow{2}{*}{ Creative } & Correlation & .295 & .538 & .699 & .634 & - \\
\hline & $p$ & .061 & .000 & .000 & .000 & \\
\hline
\end{tabular}

Source: Own elaboration.

\section{DISCUSSION}

It seems that there is a gap between practice and pedagogy, creating a space between education and the reality faced by teachers within PE settings (Gréhaigne et al., 2005). According to Casey and Dyson (2009) this existing gap between theory and practice influences the way practice, pedagogy and teacher education is implemented. Thus, breaking the link between the different ways' teachers can use as pedagogical tool in order to help students to engage. Although it seems that teaching styles can help to decrease this existing gap, since can be considered as a pedagogical bridge between elements such as teaching practice, the students' interest and the context where are woven together (Cothran et al., 2005; Kulinna and Cothran, 2003).

Although it is important to say that the context creates a strong influence among teachers' selfperception and how this affects their teaching practice. This influence not only impacts their self-perception, but also the teaching style chosen as pedagogical bridge since sometimes teaching self-perception can be different to a teaching style used in a class (Parsak and Saraç, 2019). Though, teachers tend to implement a teaching style such as the traditional that allows them to feel comfortable within their teaching identity as shown in our findings. A traditional teaching style requires that the complete authority and responsibility falls on teachers and students must follow their leadership (Kirk, 2009). This is consistent with Sáenz-López Buñuel et al. (2010) mentioning that teachers tend to see their objective serving as proxies and responsible for students learning. However, SáenzLópez Buñuel and colleagues also mention that female teachers' despite of using a traditional approach, tend to go beyond their scope and utilize other tools that can facilitate students' interest, motivation and learning.

Similarly, Piedra et al., (2014) mentions that teachers are encouraged to use a teaching style that fits their pedagogical interest and self-perception. Although, in our study this phenomenon can be explained as follows: a) teachers are expected to set the class environment, thus, should be in control of the class management. Using most likely a traditional teaching style that fits their inner teaching identity. This is consistent with Piedra 
and colleagues' study of self-reported teaching styles and perceptions among PE teachers mentioning that teachers use a variety of teaching styles in their practice, but tend to use one where they feel more productive which is normally a traditional style or command style as they described.

Contrary, self-reported perception of teaching styles describe, that teachers are unaware of reproducing mainly a traditional teaching style, since they categorized themselves as using a variety of styles among their practice. Which can be labeled as an outcome of a discourse built around practice and pedagogy over the years. It is important to mention that to the best of our knowledge there is a lack of or none reported research in Mexico that compares the relationship around gender and teaching styles within physical education teachers and the influence cultural context has over self-perception and self-reported identity as pedagogical ways of working. For instance, research focused on cognitive learning (Schell and Rojewski, 1995) suggests that individuals often learn in different ways, however, depending on the context in which the information is learned, this influence, their future decision-making process. This is consistent with Fine et al. (2001) mentioning 'knowledge is rooted in social relations and most powerful when produced collaboratively through action'. Although, Fan and Ye (2007) suggest that teaching styles can become a bridge and pedagogical tool can provide an opportunity to overcome different factors such as teachers' personal biases (e.g. cultural influence, years of experience, age, etc.) As such, it is important to acknowledge that previous experiences and cultural context can have a strong influence over the decision-making process as pedagogical self-reported and self-identity, however, it is also possible to overcome this influence and change the focus that will impact facilitating the class environment and students' learning (Nuñez Enriquez \& Oliver, 2020).

At the same time, first in regards the correlation among subscales, within the male sample we found that PE teachers tend to use more a teaching style that made them feel more comfortable such as the traditional style. Although, this shows a positive weak to moderate statistical relationship between all of the rest teaching styles implemented of the sample. This is consistent with (Kulinna and Cothran, 2003) mentioning that teachers tend to use a teaching style that helps them feel more comfortable. At the same time this provides an example of how the status quo built around the practice, context and environment of PE has been reproduced over the years as traditional factors that influence teacher's identity (Sykes, 2004). Contrary within the female sample, this group showed a positive weak, moderate and high statistical relationship between the traditional and cognitive teaching style. Which shows that female teachers tend to use a teaching style that made them feel more comfortable, as well to use a teaching style that pushes the students' learning such as attitudes and values as main goal within the class. According to
Mirandé (2008) cultural influence plays an important aspect shaping individuals' minds and specific roles. For instance, within Mexican culture, specific roles are built for males and females. Females tend to be shaped building a sense of community where values are shared. This can be consistent with the teaching style preferred by female teachers. Since external factors allowed them to see beyond their self-reported perception of teaching style.

\section{CONCLUSIONS}

It is important to say that self-reported perceptions use of teaching styles among Mexican PE teachers needs further exploration. Though, our findings showed that teachers tend to use a teaching style that allows them to feel comfortable with their own abilities regardless of gender. This is consistent with the discourse built around practice, teaching and pedagogy over the years in PE settings (Kirk, 2009). Because it seems relevant to mention that among Mexican teachers' cultural influence plays an important role when choosing a teaching style that fit teachers' abilities and self-identity (NájeraLongoria et al., 2020; Nuñez Enriquez and Oliver, 2020). Despite the fact that males showed a more general used of all teaching styles, contrary to female teachers showing to be more selective while implementing a teaching style within their classes. Although, it is recommended further exploration of the use of teaching styles and the influence within a teaching practice self-perception as a factor that can impact children and youth engagement in physical activity settings. This recommendation is because there is a lack of studies within the Mexican context that explore the use of teaching styles, self-reported perception, different pedagogical approaches, and the effect that can either facilitate and/or hinder engagement in physical education and physical activity settings.

\section{LIMITATION OF THE STUDY}

The total measurement of PE teachers in Chihuahua's school districts was one of our biggest concerns in order to obtain more accurate results. As such, it can be said that it was hard to establish a strong generalization of the results of the entire population.

\section{FUNDING}

The present work did not receive financial support of any nature for its realization.

\section{CONFLICTS OF INTEREST}

The authors declare to have no conflicts of interest.

\section{REFERENCES}

Bastick T. The measurement of teacher motivation: crosscultural and gender comparisons. In: 29th Annual Meeting of the Society for Cross-Cultural Research; New Orleans. New Orleans: Society for Cross-Cultural Research; 2000 
Brennan MD, Robison C. Gender comparison of teachers'. Sense of Efficacy Physiol Rep 1996;78(122):1-13.

Casey A, Dyson B. The implementation of models-based practice in physical education through action research. Eur Phys Educ Rev. 2009;15(2):175-99. http://dx.doi. org/10.1177/1356336X09345222.

Contreras O, De la Torre E, Velázquez . Iniciación deportiva. Madrid: Síntesis; 2001.

Cothran DJ, Kulinna PH, Banville D, Choi E, Amade-Escot C, MacPhail A, et al. A cross-cultural investigation of the use of teaching styles. Res Q Exerc Sport. 2005;76(2):193-201. http://dx.doi.org/10.1080/02701367.2005.10599280. PMid:16128486.

Cox E, Martin BC, Van Staa T, Garbe E, Siebert U, Johnson ML. Good research practices for comparative effectiveness research: approaches to mitigate bias and confounding in the design of nonrandomized studies of treatment effects using secondary data sources: the International Society for Pharmacoeconomics and Outcomes Research Good Research Practices for Retrospective Database Analysis Task Force Report-Part II. Value Health 2009;12(8):105361. http://dx.doi.org/10.1111/j.1524-4733.2009.00601.x. PMid:19744292.

Curtner-Smith MD, Todorovich JR, McCaughtry NA, Lacon SA. Urban teachersi use of productive and reproductive teaching styles within the confines of the national curriculum for physical education. Eur Phys Educ Rev 2001;7(2):177-90. http://dx.doi.org/10.1177/1356336X010072005.

Darling-Hammond L, McLaughlin MW. Policies that support professional development in an era of reform. Phi Delta Kappan 2011;92(6):81-92. http://dx.doi. org/10.1177/003172171109200622.

Delgado M. Los estilos de enseñanza de la Educación Física y el Deporte a través de 40 años de vida profesional. Retos 2015;28:240-47.

Nuñez Enriquez O, Oliver KL. 'The collision of two worlds': when a teacher-centered facilitator meets a student-centered pedagogy. Sport Educ Soc 2020;26(5):459-70. http:// dx.doi.org/10.1080/13573322.2020.1738374.

Fan W, Ye S. Teaching styles among Shanghai teachers in primary and secondary schools. Educ Psychol 2007;27(2):255-72. http://dx.doi.org/10.1080/01443410601066750.

Fine $M$, Roberts R, Torre M, Upegui D. Participatory action research behind bars. Crit Psychol 2001; 2:2145-57.

Gréhaigne J-F, Grehaigne J-F, Griffin LL. Teaching and learning team sports and games. New York: Routledge-Falmer; 2005.

Guedea-Delgado JC. Análisis de los estilos de enseñanza utilizados por los profesores de educación física del nivel primaria en la ciudad de Chihuahua. Granada: Universidad de Granada; 2010.

Harvey S, Pill S, Hastie P, Wallhead T. Physical education teachers' perceptions of the successes, constraints, and possibilities associated with implementing the sport education model. Phys Educ Sport Pedagogy 2020;25(5):555-66.

Jesus GM, Dias LA, Cerqueira PA, Assis MAA, Kupek E. Diferenças de gênero na avaliação qualitativa de atividades físicas e sedentárias de escolares de 7 a 10 anos no nordeste brasileiro. Rev Bras Ciênc Esporte 2020;42:e2013.

Kirk D. Physical education futures. New York: Routledge; 2009. http://dx.doi.org/10.4324/9780203874622.

Kulinna PH, Cothran DJ. Physical education teachers' selfreported use and perceptions of various teaching styles. Learn Instr 2003;13(6):597-609. http://dx.doi. org/10.1016/S0959-4752(02)00044-0.

Liu J. A comparison of teacher candidates and first-year teachers by gender and licensure level, in terms of their perceptions of preparation program quality, efficacy beliefs, and concerns about teaching [Dissertation]. Ohio: The Ohio State University; 2008.

Luguetti C, Aranda R, Enriquez ON, Oliver KL. Developing teachers' pedagogical identities through a community of practice: Learning to sustain the use of a studentcentered inquiry as curriculum approach. Sport Educ Soc 2018;24(8):855-66.

Merino-Barrero JA, Valero-Valenzuela A, Moreno-Murcia, JA. Análisis psicométrico del cuestionario estilos de enseñanza en educación física (EEEF). RIMCAFED 2017;17(66):225-41.

Mexico. Secretaría de Educación Pública. Aprendizajes Claves para la Educación Integral. Educación Física. Educación Básica. Plan y Programas de Estudio, orientaciones didácticas y sugerencias de evaluación. Ciudad de Mexico: SEP; 2017.

Mexico. Secretaría de Educación Pública. Programa de Educación Física. Ciudad de Mexico: SEP; 2006.

Mirandé A. Immigration and Latino fatherhood: a preliminary look at Latino immigrant and non-immigrant fathers. Lanham: Lexiton Books; 2008.

Morgan K, Kingston K, Sproule J. Effects of different teaching styles on the teacher behaviours that influence motivational climate and pupils' motivation in physical education. Eur Phys Educ Rev 2005;11(3):257-85. http://dx.doi. org/10.1177/1356336X05056651.

Mosston M, Ashworth S. Teaching physical education. San Francisco: Benjamin Cummins; 2002

Nájera-Longoria RJ, Nuñez-Enriquez O, Candia Lujan R, Lopez Alonzo SJ, Islas Guerra SA, Guedea Delgado JC. 'How is my teaching? 'Teaching styles among Mexican physical education teachers. Movimento 2020;26:e26058. http:// dx.doi.org/10.22456/1982-8918.99495.

O'Sullivan M. New directions, new questions: Relationships between curriculum, pedagogy, and assessment in physical education. Sport Educ Soc 2011;16(1):137-8.

Parsak B, Saraç L. Turkish physical education teachers' use of teaching styles: self-reported versus observed. J Teach Phys Educ 2019;39(2):137-46. http://dx.doi.org/10.1123/ jtpe.2018-0320.

Piedra J, García-Pérez R, Fernández-García E, Rebollo MA. Brecha de género en educación física: actitudes del profesorado hacia la igualdad. RIMCAFED. 2014;14(53):121.

Sáenz-López Buñuel P, Sicilia Camacho A, Moreno JIM. La opinión del profesorado sobre la enseñanza de la educación física en función del género. RIMCAFED 2010;10(37):167-80. 
Schell JW, Rojewski JW. Community and technical college teaching for thoughtful results. Community Coll J Res Pract 1995;19(2):133-50. http://dx.doi. org/10.1080/1066892950190204.

Shapira-Lishchinsky O. Israeli teachers' perceptions of lateness: a gender comparison. Sex Roles 2007;57(3-4):187-99. http://dx.doi.org/10.1007/s11199-007-9246-9.

Sykes H. Pedagogies of censorship, injury, and masochism: teacher responses to homophobic speech in physical education. J Curric Stud 2004;36(1):75-99. http://dx.doi. org/10.1080/0022027032000148306.

Tavakol M, Dennick R. Making sense of Cronbach's alpha. Int J Med Educ 2011;2:53-5. http://dx.doi.org/10.5116/ ijme.4dfb.8dfd. PMid:28029643.

Vignollet, L, Ferraris, C, Martel C, Burgos DA. Transversal analysis of different learning design approaches. JIME 2008; 2008(2).

Virla MQ. Confiabilidad y coeficiente Alpha de Cronbach. Telos 2010;12(2):248-52. 